\title{
Perceptions of Academic Librarians toward LGBTQ Information Needs: An Exploratory Study
}

\section{John Siegel, Martin Morris, and Gregg A. Stevens}

\begin{abstract}
While previous studies have examined lesbian, gay, bisexual, transgender, and queer (LGBTQ) information needs, none have addressed librarian confidence in addressing LGBTQ-themed information needs or the factors affecting this confidence. The authors used a mixed-methods survey to assess the knowledge and perspectives of academic librarians in responding to information inquiries related to sexual orientation and gender identity. Based on an exploratory factor analysis, three variables were identified: duty of care/vulnerability of inquirer, public visibility of work conducted, and personal biases and prejudices. These factors can reduce or otherwise influence the ability to meet LGBTQ information needs.
\end{abstract}

\section{Introduction}

Librarians have an ethical and professional duty to provide information to all patrons without overt judgment. The American Library Association's Library Bill of Rights and Code of Ethics, for example, urges libraries and librarians to provide resources and services to all persons regardless of their background or views. ${ }^{1}$ Other North American professional library organizations also have similar ethical recommendations on providing equitable library services to all. ${ }^{2}$

Libraries are key information sources for the LGBTQ community, playing a positive role in providing information on sexuality, gender identity, and coming out for young people. ${ }^{3}$ However, many LGBTQ patrons are reluctant to seek assistance from library staff due to fear of judgment or discrimination during a reference interaction. Although the librarian intends to be professional and obliging, the reference interaction could be affected by unintended implicit bias. ${ }^{4}$ Implicit biases are visible through nonverbal behaviors such as smiling when with someone from a favorably viewed group, or hesitation in speech and physical distance when with someone from a negatively viewed group. ${ }^{5}$ Being on the receiving end of such unfriendly nonverbal behaviors can lead to an unsuccessful reference interview and can explain the hesitancy of many LGBTQ patrons to approach the reference desk altogether. When the subject matter of a patron's request is of a sexual nature, no matter the sexual orientation or gender identity of the patron, fear of judgment can often outweigh the patron's desire for assistance.

\footnotetext{
*John Siegel is Coordinator of Information Literacy at the University of South Carolina Upstate; email: jsiegel2@ uscupstate.edu. Martin Morris is an Associate Librarian in the Schulich Library of Physical Sciences, Life Sciences and Engineering at McGill University; email: martin.morris@mcgill.ca. Gregg A. Stevens is a Health Sciences Librarian in the Health Sciences Library at Stony Brook University; email: gregg.stevens@stonybrook.edu. (02020 John Siegel, Martin Morris, and Gregg A. Stevens, Attribution-NonCommercial (http://creativecommons.org/ licenses/by-nc/4.0/) CC BY-NC.
} 
At a time when social attitudes toward LGBTQ people are becoming markedly more open and accepting, and an increasing body of literature examining the perspectives of LGBTQ library patrons has been published, little work has been conducted looking at the related perspectives and needs of academic librarians. In this study, the authors aim to provide a more holistic understanding of LGBTQ information needs by gauging librarian perspectives toward these inquiries, as well as the factors that might influence their levels of comfort and confidence in answering such requests.

\section{Literature Review}

In the nineteenth and early twentieth centuries, librarians acted as protectors of morals within their communities, limiting access to sexual content in their libraries. ${ }^{6}$ The parental role of librarians relaxed during the mid-twentieth century after the adoption of the Library Bill of Rights in 1939, as more libraries acquired sexual and other controversial materials and attempted to provide unbiased services to all. Despite this liberalization, LGBTQ materials have retained their stigma for many library patrons and staff. ${ }^{7}$

LGBTQ people must navigate a variety of barriers when accessing library resources. A substantial percentage of the published literature on library services to LGBTQ patrons has focused on the needs of patrons and the various institutional and interpersonal barriers that can prevent those needs from being met. Pierson's recent review of the literature maps out these barriers and, while a few of the barriers he identifies are specific to collections and their descriptors, the majority concern public services for LGBTQ patrons. ${ }^{8}$ Some examples of potential barriers described in the literature are based on societal conditions (such as homophobic actions and anti-LGBTQ legislation), geography (such as distance from a library in rural communities), interpersonal factors (such as body language and verbal tone), and affective factors (such as library anxiety and fear of outing oneself). ${ }^{9}$

Much of the existing literature focuses on materials and collections, such as the pioneering work of Creelman and Harris, ${ }^{10}$ Whitt, ${ }^{11}$ and Joyce and Schrader, ${ }^{12}$ which explore how lesbian and gay information needs were being met through public library collections. However, early articles focused more on the usefulness of the library materials and ease of accessing them. One cornerstone study that does address the quality of public services explores public library reference services for gay and lesbian youth. In this study by Curry, a university student posed as a younger teen and approached several reference desks to ask for book recommendations on starting a high school gay-straight alliance. The student proxy reported generally positive interactions but also received disappointingly negative reactions from several of the observed librarians. ${ }^{13}$ Curry's study is significant because it is one of the first on reference services to LGBTQ patrons. However, it focused on the patron experience, with no attempt made to determine librarian motivations for providing positive or negative services. Additionally, it was set in public libraries and not academic libraries. ${ }^{14}$

Lupien, focusing on academic libraries, surveyed students and faculty in LGBTQ/Sexual Diversity classes in several Canadian universities to determine their usage and satisfaction with their libraries' collections and services; nearly three-quarters of respondents identified as LGBTQ. ${ }^{15}$ The results indicated that 38.5 percent of the respondents had asked LGBTQrelated reference questions of library staff, and overall they were satisfied with the librarians' comfort; however, they also felt some training might be needed on LGBTQ resources. Those respondents who did not use reference services either felt they did not need help or feared 
discrimination or judgment. ${ }^{16}$ More recently, Wexelbaum has discussed the role of the academic library not only as an information resource for LGBTQ students but also as a "safe space" and an academic support to increase student retention. ${ }^{17}$

In nearly all of the literature around LGBTQ library services and collections, gender identity is included with sexual orientation under the LGBTQ umbrella. However, a recent survey into the needs and experiences of transgender library patrons shows a reluctance to use reference services because of previous bad experiences or fear of facing discrimination or ignorance at the reference desk..$^{18}$

The authors could find no published research on the motivations and biases of academic librarians in regard to LGBTQ reference service patrons and questions. However, in the health sciences there are some related studies that provide some insights. Sabin et al. used data from Harvard's Implicit Association Test (IAT) for sexuality to determine that healthcare providers have implicit preferences for patients of their own sexual orientation. ${ }^{19}$ Further work has determined that LGBTQ healthcare professionals prefer using LGBTQ librarians when seeking information. ${ }^{20}$ Although the literature is limited, it suggests that LGBTQ patrons are likely to believe that they will receive better and more culturally competent service from LGBTQ librarians than from non-LGBTQ librarians. Some possible reasons for this are that LGBTQ librarians have greater personal knowledge of LGBTQ topics through their own life experiences, that they may have greater comfort with these topics and are less easily shocked by sexual questions, and because they are less likely to have a bias against members of their own community. This is not to suggest that non-LGBTQ librarians could not provide excellent reference service, but rather that there could be an automatic, implicit preference for librarians with a similar social identity.

In this exploratory study, the authors will attempt to determine the comfort levels of academic librarians with LGBTQ-themed questions and resources and to ascertain which factors might influence their comfort level, either overtly or covertly.

\section{Methods}

One author (JS) developed a 20-question survey to determine the skill and comfort level of librarians, library staff, and students in MLS/MLIS or equivalent programs in answering questions and providing information related to LGBTQ-themes (see appendix A). This survey was approved by the Institutional Review Board at the institution where that author was employed at the time the data were gathered. A convenience sample of librarians was conducted between September 2015 and June 2016. The survey was designed to collect data from participants at various types of libraries. The present paper analyzes results specifically for academic librarians. Future research will examine findings from other respondents.

The questionnaire solicited both quantitative data, through the use of Likert scales, and qualitative data, where respondents were invited to provide further information. No identifying information was collected, and the coauthors (MM and GS) did not see any data that might potentially identify respondents. The survey was administered via SurveyMonkey, a web-based platform..$^{21}$ Participants were recruited through electronic discussion lists sponsored by the American Library Association and related organizations, including the University Libraries Section (uls-1@lists.ala.org), College Libraries Section (collib-1@lists.ala.org), Reference \& User Services Association (rusa-1@lists.ala.org), and Medical Library Association (medlib-l@ list.uvm.edu). 
Following demographic questions, participants were asked to indicate their familiarity with 15 LGBTQ-related terms using a Likert scale - ranging from "Never heard" to "Very familiar." Zimmer, Solomon, and Carson emphasize that terminology is evolving..22 As more is known about sexual orientation and gender identity, vocabulary adapts; ${ }^{23}$ the term cisgender, for instance, was introduced to the LGBTQ lexicon to differentiate individuals who identify as the biological gender they were born. Given these rapid changes, participants' knowledge of LGBTQ vocabulary is crucial to providing culturally competent assistance.

As an overall gauge of potential barriers to the quality of reference service, respondents were also asked to rate their level of confidence in serving LGBTQ information needs. The survey included nine scenario-based questions (see table 1, scenarios A-I) where participants were asked to indicate their comfort level in responding to inquiries using a Likert scale-ranging from "Very uncomfortable" to "Very comfortable." Scenario-based questions, as discussed by Wallander, are useful for determining the judgment of practitioners. ${ }^{24}$ Survey scenarios were loosely based on studies by Fikar and Keith ${ }^{25}$ and Siegel. ${ }^{26}$ The scenarios were modified and, more important, expanded to include more contemporary topics, including same-sex parenting and gender transitioning.

\begin{tabular}{|c|c|}
\hline \multicolumn{2}{|r|}{$\begin{array}{c}\text { TABLE } 1 \\
\text { Scenarios Used in Survey Questions 15-17 }\end{array}$} \\
\hline $\begin{array}{l}\text { Scenario } \\
\text { Letter }\end{array}$ & Scenario \\
\hline A & $\begin{array}{l}\text { Aiding a college student in locating primary sources (newspaper articles, interviews, and the } \\
\text { like) for a class assignment on the LGBT Stonewall riots. }\end{array}$ \\
\hline B & $\begin{array}{l}\text { Answering a request from a 65-year-old community patron for resources on LGBT safer sex } \\
\text { practices. }\end{array}$ \\
\hline C & Helping two women find information/resources on artificial insemination and starting a family. \\
\hline $\mathrm{D}$ & $\begin{array}{l}\text { Assisting a college professor in finding research/studies on the prevalence of barebacking } \\
\text { (anal intercourse without a condom) among gay men who use online chat sites. }\end{array}$ \\
\hline $\mathrm{E}$ & $\begin{array}{l}\text { Locating information/resources for a parent who is asking about understanding her young } \\
\text { son who says he wants to be a girl. }\end{array}$ \\
\hline $\mathrm{F}$ & $\begin{array}{l}\text { Proving recommendations for books, websites, and other sources to a high school teacher } \\
\text { planning an antibullying campaign that is LGBT inclusive. }\end{array}$ \\
\hline G & $\begin{array}{l}\text { Helping an adult locate self-help books or resources that cover transitioning from male to female } \\
\text { or female to male (hormone therapy, name change, employment issues, and other topics). }\end{array}$ \\
\hline $\mathrm{H}$ & Assisting a teenager (under 18) who has asked for LGBT-themed books or films. \\
\hline I & $\begin{array}{l}\text { Locating books or resources for a teenager (under 18) on "coming out" as gay, lesbian, } \\
\text { bisexual, or transgender. }\end{array}$ \\
\hline $\mathrm{J}$ & $\begin{array}{l}\text { Supplementing a library's collection with bisexual, gay, or lesbian sexually themed materials, } \\
\text { such as The Joy of Gay Sex or The Whole Lesbian Sex Book. }\end{array}$ \\
\hline K & $\begin{array}{l}\text { Based on patron requests, supplementing a library's collection with bisexual, gay, or lesbian } \\
\text { sexually themed materials. }\end{array}$ \\
\hline $\mathrm{L}$ & $\begin{array}{l}\text { Selecting gay, lesbian, bisexual, and/or transgender materials (not sexually themed), such as } \\
\text { Legalizing LGBT Families (book) and Growing up Trans(gender) (documentary). }\end{array}$ \\
\hline M & $\begin{array}{l}\text { Based on patron requests, selecting gay, lesbian, bisexual, and/or transgender materials (not } \\
\text { sexually themed) for a library's collection. }\end{array}$ \\
\hline
\end{tabular}


In addition, respondents rated their comfort level on four scenarios (see table 1, scenarios $\mathrm{J}-\mathrm{M}$ ) related to collection development. Although not a primary focus of the survey, selection of materials can impact information access. Adler found that librarians' ability to determine users' needs and acquire materials can impact research success. ${ }^{27}$ Librarians who are unfamiliar or uncomfortable with purchasing LGBTQ-themed books and other library resources may be less likely to refer patrons to such materials.

Given the complexity of terminology and range of information needs, participants were also asked about their perceived need for training. Respondents indicated their preference for training opportunities, ranging from in-person conferences to webinars. The final (optional) question was open-ended and invited free-text, qualitative responses on any topic covered by the survey

\section{Data Analysis}

Statistical analysis of survey data was conducted in R 3.3.3. $3^{28}$ and RStudio 1.1.442 ${ }^{29}$ using the psych, ${ }^{30}$ nFactors, ${ }^{31}$ psy, $^{32}$ and paralle ${ }^{33}$ libraries. Qualitative data were analyzed in Excel using open coding to identify themes.

For the 13 quantitative scenario-based questions, responses were analyzed to determine whether they could be explained by a smaller number of more fundamental motivations and influences and if there was an underlying structure underpinning the responses. To achieve this, an exploratory factor analysis (EFA) was conducted. Loadings were calculated both with no rotation and with promax rotation (frequently recommended for studies with human subjects ${ }^{34}$ ). As the values obtained from promax rotation did not provide additional assistance in interpreting our analysis, we proceeded with the results obtained from no rotation, and it is these results that are reported in findings. One author $(\mathrm{MM})$ conducted three analyses - one for all respondents, one for LGBTQ respondents, and the third for non-LGBTQ respondents. The suitability of the survey data for an EFA was confirmed by subjecting them to the Kaiser-Meyer-Olkin (KMO) Measure of Sampling Adequacy ${ }^{35}$ and Bartlett's Test of Sphericity, ${ }^{36}$ both of which passed.

To further test the reliability and internal consistency of the survey, and thus its suitability for an EFA, Cronbach's Alpha was calculated. Further insights from the scenario responses were provided by calculating the means of all responses to each scenario. Sample T-tests were also performed to compare the differences in how respondents replied to each question.

\section{Findings}

A total of 376 responses was received from librarians in the United States with an ALA-accredited LIS degree who indicated they were currently working or volunteering in an academic library. Of these, 29 percent $(n=110)$ identified as LGBTQ. Most respondents earned a library and information science degree at least 10 years ago $(n=163,43 \%)$. Full demographic details for the cohort of respondents can be found in appendix B.

\section{Confidence in Serving LGBTQ Information Needs}

The overwhelming majority of respondents (87.6\%) either "agreed" ( $\mathrm{n}=125,35.3 \%)$ or "strongly agreed" ( $n=185,52.3 \%)$ that they are confident in serving LGBTQ information needs; for LGBTQ respondents, this rises to 97.3 percent. Separate analyses by both age group and region of the United States demonstrates that these confidence levels are not statistically significantly different between age groups or regions of the United States. 
TABLE 2

Answers to Question: "I am confident in serving LGBT information needs." $(\mathbf{n}=376)$

\begin{tabular}{|l|c|c|c|}
\hline & $\begin{array}{c}\text { All Respondents } \\
(\mathbf{n = 3 7 6 )}\end{array}$ & $\begin{array}{c}\text { LGBTQ Respondents } \\
(\mathbf{n = 1 1 0 )}\end{array}$ & $\begin{array}{c}\text { Non-LGBTQ Respondents } \\
(\mathbf{n = 2 4 3 )}\end{array}$ \\
\hline Strongly Agree & 185 & 81 & 104 \\
\hline Agree & 125 & 27 & 95 \\
\hline Neutral & 35 & 2 & 33 \\
\hline Disagree & 7 & 0 & 7 \\
\hline Strongly Disagree & 2 & 0 & 2 \\
\hline No Response & 22 & 0 & 2 \\
\hline
\end{tabular}

The free-text replies contain many comments from respondents that are consistent with this majority view:

"In the academic institution where I work, I am not aware of and have never seen any staff people who are uncomfortable serving the LGBT community, and we actively promote services and collections with LGBT content - with pride."

"I'm comfortable serving any LGBT needs that actually fall within the scope of my library - I have ended up working with patrons who knew that I was gay when I wasn't the best expert for their subject."

Some respondents draw a distinction between different possible meanings of "confident." Two respondents, for example, distinguished between confidence in their expertise to deal with the subject matter and level of comfort in handling questions on more intimate aspects of LGBTQidentity.

"[...] I'm comfortable in the social sense with these [questions], and I am confident that I have the necessary professional expertise. I suspect I would be less comfortable, again in the social sense, discussing the intimate details of someone's sexuality no matter what their sexual orientation - that's just me. However, I would hope to provide whatever help I could, but I would probably feel less confident of my expertise in this area."

"[...] I have no problem serving LGBT patrons and have some basic familiarity with the subjects you named, but would not feel confident doing collection development or providing deep scholarly research assistance in this area as I do not know the literature well."

\section{Familiarity with LGBTQ Lexicon}

The terminology used to describe different members of the LGBTQ community is evolving. ${ }^{37}$ Howard and Knowlton stress that correct use of terminology is important to be inclusive and make patrons feel comfortable. ${ }^{38}$ In this survey, most respondents (90\% or higher) were most familiar with established terms (like gay, lesbian, bisexual, transgender, and sexual orientation) that are more common. Approximately half of respondents were less familiar or had never heard newer terms related to gender identity (such as genderqueer, cisgender, gender binary, and gender variant). 


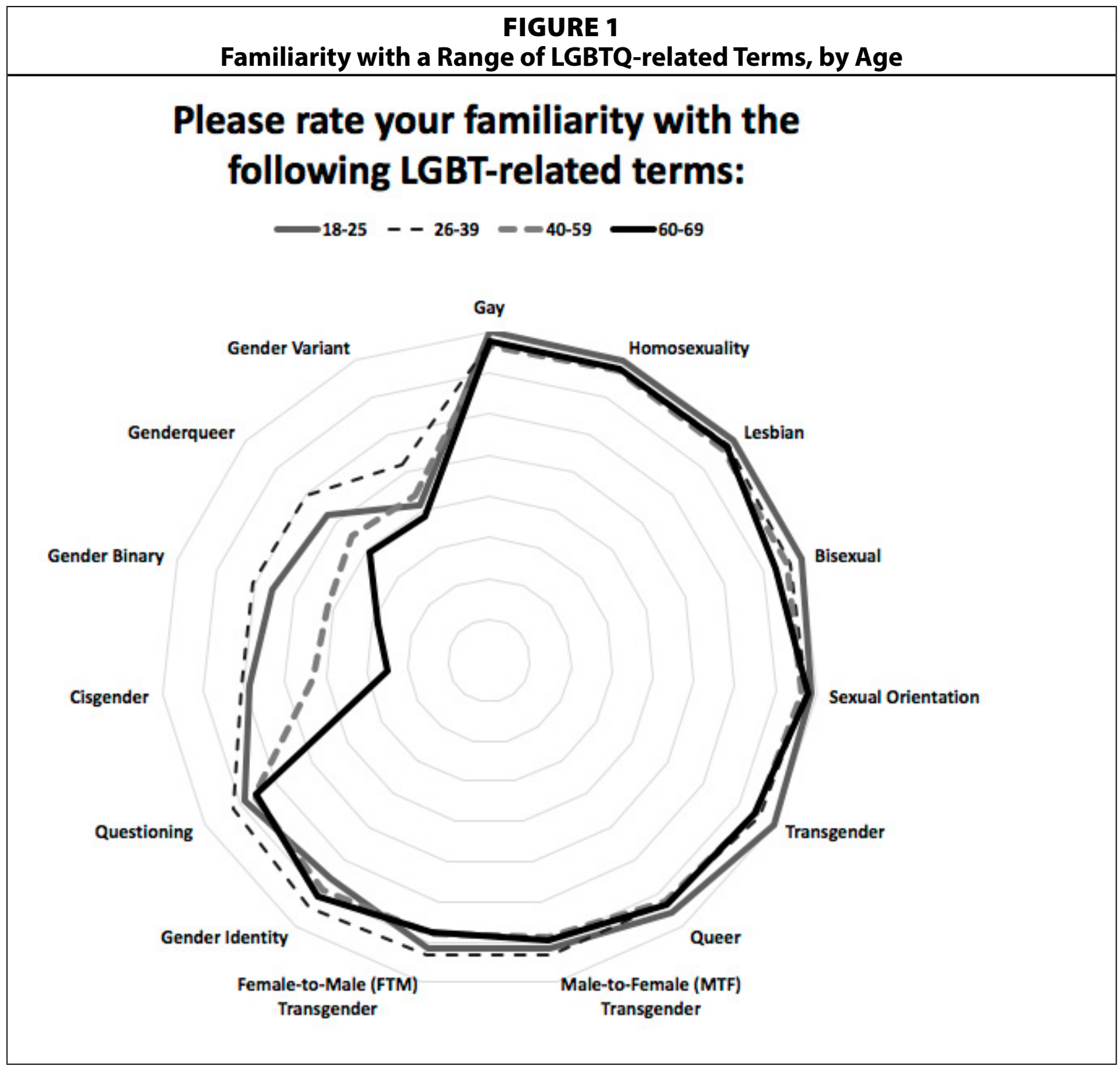

As shown in figure 1, the most knowledgeable group are 26- to 39-year-olds. Knowledge starts to drop off more quickly for librarians above age 40 - and more for those above age 60.

One respondent interestingly touched on the particular importance of new and more accurate terminology to younger people, connecting this to the need for training to stay current (emphasis added):

"My institution is fairly accepting and comfortable with issues in the queer community, but I realize that there will always be things I don't know, especially when dealing with a younger audience. Faculty and I may have similar backgrounds, experiences, etc. to help us find common ground when framing research issues - but these students are living in a brave new world. I know I will need help now and going forward in keeping up to date with preferred terminology, representation in pop culture, activism, online environments, etc." 


\section{Training Needs in Meeting LGBTQ Information}

Most respondents indicated a strong interest in training, both in the quantitative responses and open-ended responses in the "Other" field. However, there was a statistically significant (as demonstrated by the $P$-value) lower level of interest in training for respondents between the over 40 (in the 40-59 and 60-69 age cohorts) and those in the younger cohorts, with the most statistically significant difference being between the 26-39 age group and the 60-69 age group. There was no statistically significant difference between the cohorts from the four census regions of the United States.

\begin{tabular}{|c|c|c|c|c|c|}
\hline \multicolumn{6}{|c|}{ 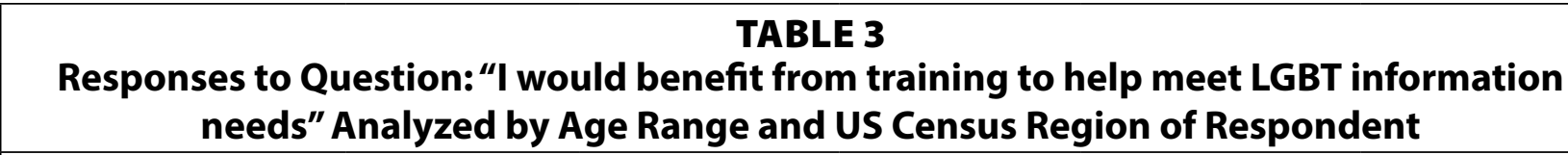 } \\
\hline \multicolumn{6}{|l|}{ Age Range $(n=376)$} \\
\hline Age Range & $\begin{array}{l}\text { Strongly } \\
\text { Disagree }\end{array}$ & Disagree & Neutral & Agree & $\begin{array}{c}\text { Strongly } \\
\text { Agree }\end{array}$ \\
\hline $18-25$ & 1 & 0 & 0 & 7 & 5 \\
\hline $26-39$ & 2 & 5 & 21 & 81 & 60 \\
\hline $40-59$ & 3 & 5 & 28 & 83 & 39 \\
\hline $60-69$ & 2 & 0 & 12 & 16 & 7 \\
\hline \multicolumn{6}{|c|}{$P$-value: 0.037 (Fischer Exact Test-Freeman-Halton extension, $10^{7}$ iterations) } \\
\hline \multicolumn{6}{|c|}{ b. US Census Region $(n=357)$} \\
\hline US Census Region & $\begin{array}{l}\text { Strongly } \\
\text { Disagree }\end{array}$ & Disagree & Neutral & Agree & $\begin{array}{c}\text { Strongly } \\
\text { Agree }\end{array}$ \\
\hline Midwest & 1 & 1 & 19 & 43 & 22 \\
\hline Northeast & 1 & 2 & 14 & 40 & 11 \\
\hline South & 4 & 3 & 19 & 72 & 39 \\
\hline West & 0 & 1 & 7 & 32 & 26 \\
\hline
\end{tabular}

Participants showed a strong preference for training options that are local or available online. In addition, 39 percent of respondents indicated an interest in learning from electronic forums, such as listservs. Two respondents indicated travel costs and limited professional development budgets as a factor in training preference. A small number of respondents, however, indicated they would be interested in traveling to conferences for training opportunities.

The need and desire for training was a dominant theme in the open-ended responses, with 25 comments on this subject. For example:

"A big part of helping our LGBTQ patrons is also making sure that our workplaces are positive and supportive - training focused on employees would also be great."

"This likely falls outside the bounds of the study, but I would be interested in receiving training on how to navigate homophobia in patrons while simultaneously maintaining an inviting attitude and positive library atmosphere." 
Several respondents mentioned a desire for institutional training, possibly offered by academic units such as gender studies. Others either expressed interest in or had attended Safe Zone training, which is typically offered by student affairs offices and includes content such as terminology, the "coming out" process, issues of discrimination and privilege, and campus, local, and national resources. ${ }^{39}$ Forming relationships with student groups and other academic units was also mentioned in several comments.

Many participants were interested in more advanced, in-depth training in areas such as intersectionality and the needs of transgender persons. Others sought online resources to assist in providing library services, including collection development. Respondents also indicated an interest in tools such as LibGuides, bibliographies, online videos, and clearinghouses.

\begin{tabular}{|l|c|}
\hline \multicolumn{2}{|c|}{ TABLE 4 } \\
Responses to Question “If offered, which types of training opportunities on serving LGBT \\
information needs might you be interested in? You may select more than one answer." (n = 376) \\
\hline & Responses (\%) \\
\hline Virtual/Online Conferences/Presentations/Workshops/Webinars (live or prerecorded) & $269(72 \%)$ \\
\hline Local Conferences/Presentations/Workshops & $205(54 \%)$ \\
\hline Self-paced Online Courses (continuing education/not for credit) & $185(49 \%)$ \\
\hline Regional Conferences/Presentations/Workshops & $164(44 \%)$ \\
\hline State Conferences/Presentations/Workshops & $153(41 \%)$ \\
\hline Electronic Discussion Groups [listservs] to ask questions and share information & $146(39 \%)$ \\
\hline None. I am not interested in training opportunities. & $33(9 \%)$ \\
\hline Other & $25(7 \%)$ \\
\hline $\begin{array}{l}\text { NOTE: } \text { As respondents were allowed to select more than one answer, the total is higher than the response rate } \\
\text { of 376 respondents. }\end{array}$ \\
\hline
\end{tabular}

\section{Underlying (Latent) Factors Influencing Comfort with LGBTQ-Related Information Needs}

To assess the suitability of the data for an EFA, an initial calculation of Cronbach's alpha was performed; all scores exceeded 0.9, denoting high internal consistency.

The optimum number of factors to extract through EFA was determined by comparing the results of the scree test, the Very Simple Structure test and a parallel analysis (Monte Carlo method), which strongly suggested that 3 factors would be sufficient. A variety of tests were conducted to confirm this, and the results of these tests are provided at the bottom of table 5; the analysis therefore proceeded with the EFA analysis on that basis. The two scree plots strongly suggesting that 3 factors are sufficient are provided in figure 2 .

The results of this analysis are provided in table 5 and form the basis for much of the discussion.

\section{Open-Ended Responses}

A concluding (optional) question invited additional comments about serving LGBTQ information needs. There were 98 submitted responses covering all areas of the survey, particularly focusing on training, reference, collections, and advocacy. Most of the comments were neutral in tone, with no pro- or anti-LGBTQ bias expressed. 


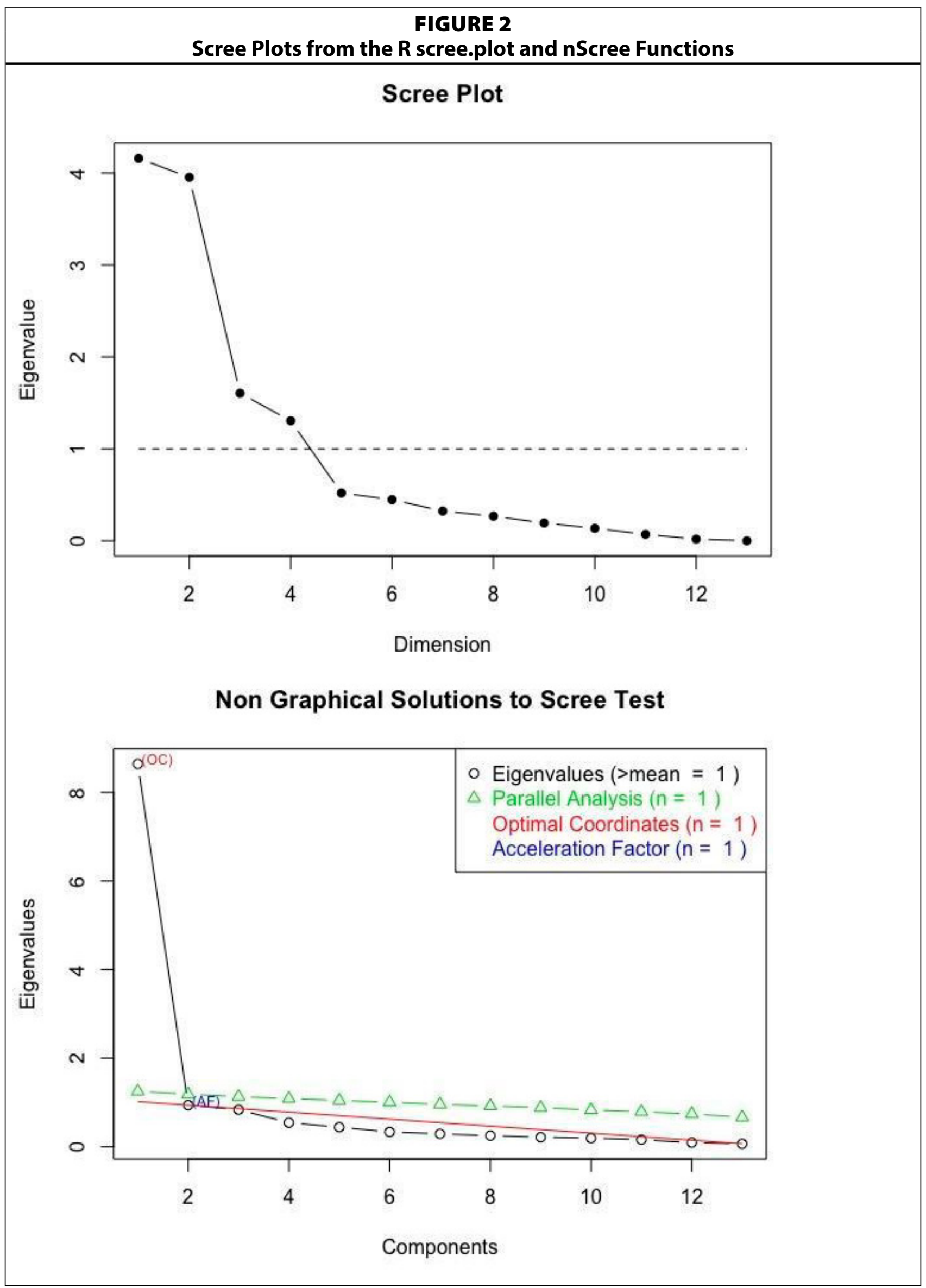




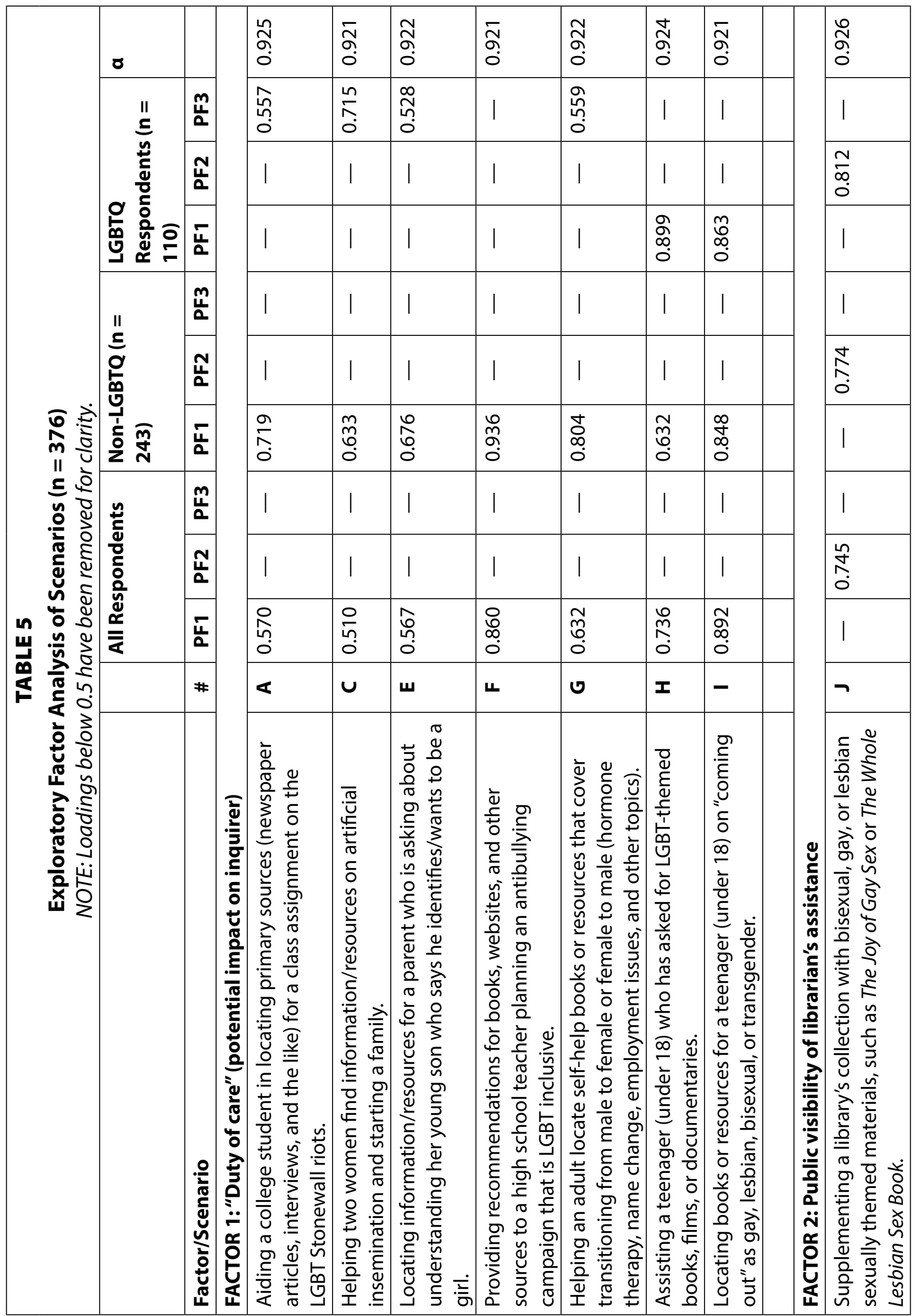




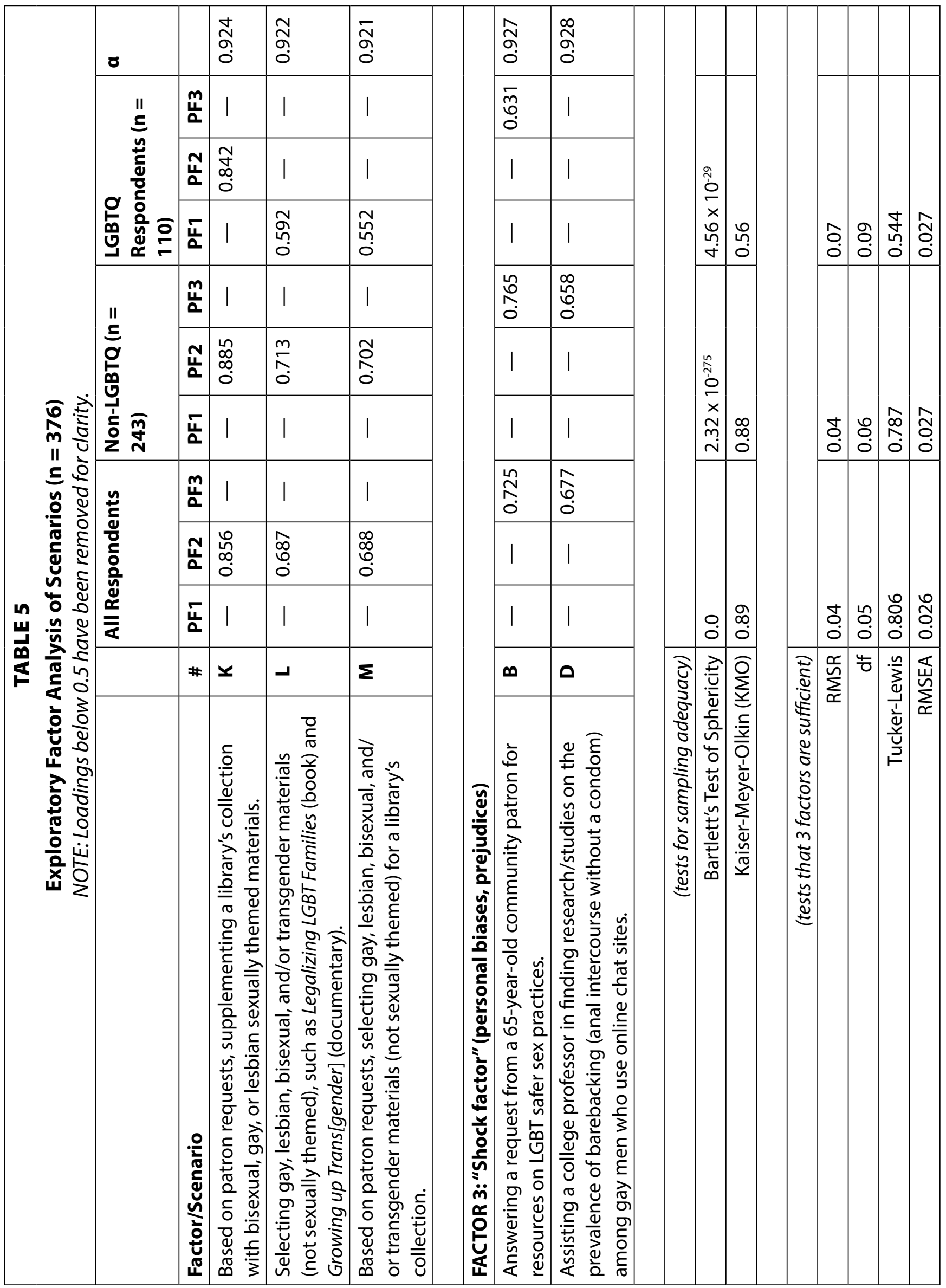


Approximately one-quarter of comments $(n=24)$ explicitly expressed support with the LGBTQ community. Several respondents $(n=10)$ disclosed in their comments that they either identified as LGBTQ or that someone close to them was LGBTQ. Sixteen respondents mentioned that their library or institution has a welcoming environment for LGBTQ patrons, of which the majority also mentioned participation in Safe Zone training.

In contrast, a small number of comments $(n=4)$ reflected negative biases toward LGBTQ persons. Five respondents similarly mentioned that they work in conservative environments such as religiously affiliated colleges, or in conservative states; two of these respondents explicitly stated that they still provided LGBTQ-positive services despite barriers.

\section{Discussion}

\section{Factors Affecting Librarian Comfort with LGBTQ Information Needs}

Exploratory factor analysis suggests that three underlying factors influence how librarians approach LGBTQ information needs, and we describe these factors in detail below. In attempting to ascertain the nature of these three factors, each factor was considered in turn and observed to what extent it affected the response to each particular scenario for all respondents as a whole (in other words, the size of the loading given in table 5), for non-LGBTQ respondents, and finally for LGBTQ respondents. The likely nature of each factor was then inductively ascertained. Following standard guidance, loadings below 0.5 were ignored, and these results are removed from the analysis in table 5 for clarity. ${ }^{40}$

\section{Factor 1: Duty of Care/Professional Responsibility}

The scree analysis (figure 2, above) shows that Factor 1 (henceforth PF1) is the factor that by far most heavily influenced librarian responses to LGBTQ information needs. For participants as a whole, the heaviest weights for this factor are for those scenarios relating to inquiries from or relating to young people (scenarios I, F, and H), where the information is being solicited for often highly personal reasons. The information provided by the librarian in response to these questions could potentially have a profound effect on a vulnerable inquirer at a formative time in their life. It is also possible that the responding librarian may be concerned about violating the wishes of the parent(s) of the inquirer.

Three further scenarios (C, E, and G) relate to inquiries from adults (in one case on behalf of their son) and have lower loadings than the questions coming directly from a young person. While still very important questions, they come from adults who are less vulnerable and more mature. Therefore, the information is less likely to have a formative and profound impact on the inquirer's life.

A final scenario which attracts a lower but still significant (that is, $>0.5$ ) loading is A, where a young person is requesting purely historical information for a class assignment. Scenarios relating to highly sexual questions (scenarios $B$ and D) and to collection development (scenarios J, K, L, and M) do not attract significant loadings for PF1 and are, according to this analysis, influenced by other underlying factors.

From this inductive analysis, the authors believe that PF1 has a strong connection with librarian duty of care and professional responsibility, particularly when it involves vulnerable inquirers such as young adults. For these questions, the librarians' responses appear to have been guided by concern for the impact of the information on the user and for the librarian's responsibility in providing accurate and culturally competent information. For LGBTQ 
librarians, this factor contains an additional responsibility to the LGBTQ community, with an implied responsibility to provide support and encouragement to LGBTQ patrons. This fits with the positive implicit bias toward members of one's ingroup.

Several of the open-ended comments support the interpretation that this is a significant underlying factor, including the following:

"In general, I would say I am equally as comfortable providing Library assistance of a 'personal nature' to LGBTQ users as I am to heterosexual/cisgender/undisclosed users... That is to say, I would be slightly uncomfortable due to the highly personal nature of the request as opposed to the type of content to be dealt with. However, I would strive to maintain the library as a safe space for all users."

"I am the library director at a rural community college. I am also the advisor for the Campus Pride student club and one of the campus safe zone trainers. We are serving more students identifying as transgender. I have added LGTBQ material to the collection. While I am quite comfortable with all the scenarios you listed, I am not sure all of my staff is but they tell me they are. I am not sure how to gauge whether the library as a whole is LGTBQ supportive or if it is just me."

"I think one of the issues with minors is navigating the balance of providing information without violating the parental views, especially if my actions would lead to the teen not having library access because of parental restrictions or lead to negative parental responses such as 'retraining' or abandonment."

"[...] As for the question about assisting a parent find [ing] information concerning a child with gender identity questions, I also might be uncomfortable if the parent was not in support of the child's chosen gender identity since I know kids in this situation sometimes contemplate/commit suicide. I would feel compelled to share this information even if the parents were seeking media that was not in support of a person identifying as another gender, because the child's life could be in danger."

An interesting difference can be seen between LGBTQ and non-LGBTQ respondents for these scenarios. In the case of scenarios $\mathrm{H}$ (Assisting a teenager [under 18] who has asked for LGBT-themed books, films, or documentaries) and I (Locating books or resources for a teenager [under 18] on "coming out" as gay, lesbian, bisexual, or transgender), both of which relate to helping teenagers, professional duty of care is still overwhelmingly the factor that influences all respondents, whether LGBTQ or not. However, for scenarios A, C, and G, which relate to assisting adults, it is PF3 that most influences the comfort levels of LGBTQ respondents. This is discussed in more detail in the subsections that follow.

\section{Factor 2: Public Visibility}

From the scree analysis, it can be seen that Factors 2 (PF2) and 3 (PF3) have a still significant, but much lower impact on respondent replies to the scenarios. Factor 2 has high loadings for the four scenarios related to collection development (scenarios J, K, L, and M), with higher 
loadings for the two scenarios relating to sexually themed materials (scenarios J, K) and slightly lower loadings for materials that are not sexually themed (scenarios $\mathrm{L}, \mathrm{M}$ ). The significant difference between these scenarios and those affected principally by PF1 is that they are publicly visible (within their professional community), could be directly ascribed to an identifiable librarian who has an associated public responsibility and who might fear damage to their professional reputation, and whose choices might be subject to censorship.

The authors conclude that PF2 is mostly concerned with public visibility of the work and with the potential to be publicly identifiable (within the library or the broader community) as the librarian who has carried out the work. Fear of challenge to a librarian's collection development decisions may drive some of this, as well as the related fear of censorship from administration, or a public backlash. A more general fear of harming one's reputation within the community and within the organization is likely to be a motivating factor for self-censorship.

An interesting difference between LGBTQ and non-LGBTQ respondents is apparent for this factor. While public visibility is significant for the entire cohort of respondents, the same is not true for the subset of LGBTQ respondents. For this group, the selection of nonsexual materials for the library collection is most affected by PF1 (professional duty of care/responsibility), suggesting that they are less concerned about the public visibility of such materials and the fear of negative repercussions for the librarian choosing to display them publicly, and more concerned about ensuring the availability of accurate and appropriate information. However, for the selection of sexually themed materials, PF2 weights for LGBTQ respondents are similar to those for non-LGBTQ respondents, suggesting that they have equal concerns about the public visibility of sexually themed materials.

One may also fear being viewed as LGBTQ when they in fact are not, a form of internal homophobia or transphobia, or may worry about administrative disapproval, a form of organizational homophobia/transphobia.

"I work for a conservative Christian academic library and while I personally (as a lesbian) wouldn't have a problem with answering these questions, I would be concerned about having to justify purchases to the administration. As a result, I would definitely come to them with research and reasons for all of my purchases for the library whether it be patron requested, curriculum driven, etc."

"Your question "Supplementing a library's collection with bisexual, gay, or lesbian sexually themed materials, such as the 'The Joy of Gay Sex' or 'The Whole Lesbian Sex Book.'" I replied neutral because I work in a conservative area and I would be hesitant to add any sexually themed materials to our collection at all. LGBT or straight. I would however be happy to ILL materials for our patrons with no problem [...]."

\section{Factor 3: "Shock Factor" (Personal Biases and Prejudices)}

Factor 3 (PF3) principally affects the two scenarios relating to face-to-face inquiries about LGBTQ sexual practice, with the lower loading attached to the more academic request for information on research into barebacking (scenario D) and the higher loading attached to the request for information to support a personal sexual practice (scenario B), when considering the entire cohort of respondents. 
These comparative loadings in the analysis suggest strongly that PF3 is linked to personal values, what might be called the "shock factor": a strong conflict between the librarian's personal value system and the content of the inquiry.

In the view of the authors, this factor is the most likely of the three to be the root cause of feelings of stigmatization or discrimination on the part of an LGBTQ inquirer. This may be manifested as overt moral judgments on the part of the librarian, a form of external bias. It might also be more subtly expressed in unintended ways, leading to microaggressions against the inquirer, a form of internal bias. Nonverbal behavior such as verbal tone or eye-rolling could be expressions of this internal bias.

Again, there is a significant difference between LGBTQ and non-LGBTQ respondents. For LGBTQ respondents, PF3 only impacts their responses to scenario B (covering a personal sexual practice) but appears to have no impact for scenario $D$ (covering academic research into a sexual practice). The authors believe this is likely to be because discomfort with questions relating to personal sexual practice can be felt by librarians regardless of their sexual orientation or gender identity. However, in the case of scenario D, it appears likely that the difference in responses is due to the specific LGBTQ nature of the inquiry.

In fact, this aspect of the analysis demonstrates an interesting correlation in responses between LGBTQ and non-LGBTQ people for both PF2 and PF3. For both factors, the authors notice that the comfort levels of all respondents are negatively affected when the nature of the work is related to questions of personal sexual practice (that is to say, display of sexually explicit material for PF2, and responding to an inquiry on personal sexual practice for PF3). These results suggest an erotophobic discomfort with this type of work that is not affected by the sexual orientation or gender identity of the librarian.

Several comments from respondents address this discomfort:

"I'd probably feel uncomfortable helping *anyone* find safe sex practices. I think I would approach it in the same way I approach any uncomfortable subject a patron asks for help with: just treat it as an ordinary reference question, try to do a good reference interview (maybe while blushing) and be as matter-of-fact about it as I can."

"In terms of materials discussing actual sexual practice, I am equal opportunity. I am just as uncomfortable discussing sex techniques with straight people as with gay people."

"[...] I am in a position to hire staff here and am extremely clear in the interview that our population includes a very diverse group of individuals who must all be extended our very best service. I have to say that the scenario presented in this study involving research about sex made me uncomfortable - it was not because it was men having unprotected sex with men, it is because I'm not used to helping someone find research material on sexual activity. I would be a professional, put my personal discomfort aside, and help the professor find what was needed. I've done this before with other research questions that made me uncomfortable."

It was noted above that, for LGBTQ respondents, $\mathrm{PF} 3$ is the most significant factor in four scenarios (A, C, E, and G), whereas for non-LGBTQ respondents PF1 is the most significant influencing factor for these scenarios. All four of these scenarios relate to adults asking for 
information on personal matters that are not sexual in nature. The authors believe that, while duty of care and professional responsibility remain important, for these scenarios the LGBTQ librarians may be less affected by concerns that they will give inappropriate advice, or fail to display cultural competence, and more affected by their own personal value systems, and that they may be displaying a positive internal bias toward people who are facing life decisions similar to those possibly faced by the attending LGBTQ librarian.

\section{Limitations}

This survey was composed of a self-selected sample of respondents. As such, there are some inherent limitations to the study. More than a quarter of respondents $(29 \%)$ identified as LGBTQ, while current estimates indicate that 4.5 percent of the US population identifies as LGBTQ. ${ }^{41}$ While this higher concentration is useful in gauging the behaviors and perspectives of LGBTQ librarians, this also probably skewed the aggregate responses. Given the subject matter, it is possible that some respondents completed the survey because of strong feelings regarding the LGBTQ community. Those who strongly support the LGBTQ community and know people who identify as such may have been more motivated to take the survey. It is also conceivable that some librarians avoided the survey either because they have a negative personal opinion of the LGBTQ community or because their employer has anti-LGBTQ policies for conservative religious or cultural reasons.

Another potential limitation involves the questions themselves. In the open responses, some respondents indicated confusion as to whether "comfort" referred to ability or personal judgment. As the survey was designed to collect responses from librarians at different types of libraries, including public and school media centers, not all of the scenarios would be relevant to the work experiences of academic librarians. Some of the scenarios, including $\mathrm{E}$ and $\mathrm{H}$, involved minors and therefore were not necessarily those that an academic librarian would encounter, so answers were likely hypothetical. Similarly, librarians who do not work in public services, such as technical services librarians, likely answered the survey questions based on their perceived reactions to scenarios outside their work duties.

One final criticism of the survey involved the vocabulary used versus the respondents' personal knowledge of LGBTQ-related vocabulary. For example, in the open responses, some participants asked why the term pansexual was not included in the Likert list of LGBTQrelated terms or in the scenarios. These respondents were critical of the survey for not being sufficiently encompassing of the spectrum within the LGBTQ community.

\section{Conclusion}

\section{Keeping Up with a Rapidly Changing World}

Based on the analysis of the responses, most academic librarians are willing, and frequently enthusiastic, to assist patrons with LGBTQ-themed information needs. Nonetheless, our deeper factor analysis demonstrates that, in fact, various latent influences can reduce or otherwise affect actual comfort levels and competence to meet these needs. This demonstrates that there is still a strong need for training, despite increasing social acceptance for LGBTQ people.

It should be recognized that, despite rapidly improving social circumstances for LGBTQ people, there is still much progress to be made; and, regrettably, not all librarians are as willing to improve and provide objective service. One highly negative open-ended comment illustrates this particularly clearly: 
"The consciously chosen perversion of LGBT should not be promoted by libraries due to its historically and contemporary destructive impact on all aspects of society e.g. public health, economics, promoting personal immorality, and overall moral decadence and degeneration. Where this acute societal problem is concerned librarians should enhance their collections documenting the destructive consequences of this lifestyle. Librarians must direct users to resources such as epidemiological data, the increased occurrence of depression among LGBT populations, the dangerous consequences of raising children with confusion about appropriate gender role, the promiscuity of GLBT populations, the efforts of LGBT proponents and apologists to personally destroy those of us opposing their political objectives and personal degeneracy, point out the destructive historical consequences widespread LGBT lifestyles have had on nations throughout history, and show how accepting the reality that we are created by God and intended by him to live as monogamous heterosexuals [sic]."

Many librarians recognize that they need more training, such as on LGBTQ terminology and culture, and information resources, and often have a critical recognition of their own latent biases, which may help them to better address information needs. The results indicate that easily accessible and inexpensive training would be particularly well received by librarians.

However, while continuing education can improve the knowledge base of existing librarians, the introduction of LGBTQ information needs and resources in the library and information science (LIS) curriculum is perhaps a stronger long-term solution for reducing these disparities. ${ }^{42}$ Ultimately, though, further research will be needed to map out in more detail how well librarians are addressing LGBTQ information needs and to what extent education is improving librarian skills and confidence in serving the needs of this community.

\section{Acknowledgments}

The authors gratefully acknowledge the assistance of the following: Daz Saunders (for introducing MM to exploratory factor analyses and for his considerable support throughout this project), José Carrera of the McGill University Statistics Consult Service (for his guidance on certain other analyses in this paper), and Kayla Cook-Cossey, Dr. Alan D'Aiello, Frank Fajado, Teresa Holliday, Rodney Lippard, Raymond McCarthy, and Andrea Miller-Nesbitt for their constructive comments during the editing of this paper. 


\section{APPENDIX A. Serving Lesbian, Gay, Bisexual, and Transgender (LGBT) Information Needs}

This study is being conducted to investigate the knowledge, attitudes, and experiences of librarians, library staff, and students in library/information science programs in responding to LGBT information needs. The results of this study are anticipated to be included as part of a journal article and/or presented at professional conferences.

Your participation is strictly voluntary. However, your assistance in filling out this webbased survey would be appreciated. This survey will ask questions about your experience, knowledge, and comfort level in serving LGBT information needs. This survey should take approximately 15-20 minutes to complete.

You must be at least 18 years old to participate in this survey.

Your submission of this survey indicates your consent to participate in this study. Please be assured that your responses will be anonymous. There are no questions that request self-disclosure of information that could be used to identify you. It is not anticipated that this survey will provide you, as the participant, with direct benefit and no loss. Please note that you may experience minimal discomfort when answering questions about personal experiences and comfort level. You are free to discontinue participation at any time during the survey.

Survey results will be kept securely for three (3) years on campus, in compliance with federal requirements.

If you have questions about this study, you can contact the researcher directly.

This study has been reviewed and approved by the researcher's Institutional Review Board (IRB). The IRB has determined that this study meets the ethical obligations required by federal law and university policies. If you have questions regarding your rights as a research subject, please contact the Research Compliance Officer.

1. Please indicate which of the following most closely represents your current status:

$\square \quad$ Librarian

$\square \quad$ Paraprofessional/Library Staff Member (Current or Retired)

$\square$ Student (MLS/MLIS/Equivalent Program)

$\square \quad$ Other (please specify)

2. Have you earned an MLS, MLIS, or equivalent library/information science degree accredited or recognized by the American Library Association (ALA)?

$\square \quad$ Yes, my degree is ALA accredited or recognized.

$\square$ No, my library science/equivalent degree is from a United States (US) program that is not ALA accredited.

$\square$ No, my library science/equivalent degree is from a foreign program that is not recognized by ALA.

$\square \quad$ No, I do not have a library science/equivalent degree. - SKIP TO \#4

$\square \quad \mathrm{I}$ am in the process of earning a library science/equivalent degree. - SKIP TO \#4 
3. How long have you held the MLS, MLIS, or equivalent library/information science degree?

$\square$ Less than 1 year

ㅁ $1-4$ years ago

ㄴ 5 -9 years ago

10 or more years

4. How long have you worked or volunteered in libraries/information center settings?

Never - SKIP TO \#12

$\square$ Less than 1 year

1-4 years

5-9 years

$\square$ More than 10 years

5. Do you currently work or volunteer in a library/information center?

口 Yes

- No - SKIP TO \#12

- Retired - SKIP TO \#12

6. Which of the following describe(s) the library/information center where you currently work or volunteer? You may select more than one answer.

$\square$ Academic

$\square$ Archives/Special Collections

$\square$ Federal

$\square$ Law/Legal

- Medical

․ Public - City

Public - County

Public - State

- School Media

- Special (Company, Organization, or Other Group)

$\square$ Other (please specify)

7. Which of the following roles do you have at your library/information center? You may select more than one answer.

$\square$ Acquisitions

- Administration

- Archives/Special Collections

$\square$ Cataloging

$\square$ Circulation

- Collection Development (selecting materials)

$\square$ Community Outreach

- Information Technology (that is, printers, copiers, scanners, and the like)

口 Interlibrary Loan

Library/Research Instruction

Marketing/Promotion 
$\square$ Outreach to departments/groups/offices/units within the institution (such as University Writing Center)

$\square$ Reference/Research Assistance

- Systems (in other words, integrated library system [ILS], discovery layer [EDS, Primo, and the like], proxy server, or other systems)

$\square$ Other (please specify)

8. Is the library/information center located in the United States?

$\square$ Yes

․ No (please specify location) - SKIP TO \#10

9. Please select the state where the library/information center is located.

10. Which of the following best describes the library/information center location?

$\square \quad$ Rural (open countryside or places with fewer than 2,500 people)

$\square \quad$ Rural (more than 2,500 people)

$\square$ Town

$\square$ City (not considered urban)

$\square$ Urban

$\square$ Suburban

$\square$ Other (please specify)

11. In which role(s) have you dealt with LGBT information needs at your library/information center? You may select more than one answer.

Examples: Answering reference/research questions that have an LGBT aspect, selecting LGBTthemed resources as part of collection development, and cataloging new LGBT-focused books.

$\square$ None/Unsure

$\square$ Acquisitions

$\square$ Administration

Archives/Special Collections

$\square$ Cataloging

$\square$ Circulation

- Collection Development (selecting materials)

- Community Outreach

- Information Technology (that is, printers, copiers, scanners, and the like)

口 Interlibrary Loan

$\square$ Library/Research Instruction

- Marketing/Promotion

- Outreach to departments/groups/offices/units within the institution (such as University Writing Center)

- Reference/Research Assistance

- Systems (in other words, integrated library system [ILS], discovery layer [EDS, Primo, and the like], proxy server, or other systems)

$\square \quad$ Other (please specify) 
12. Do you identify as lesbian, gay, bisexual, and/or transgender?

口 Prefer not to disclose

口 Yes

$\square$ No

13. Please indicate your age:

口 Prefer not to disclose

18-25

26-30

31-39

40-49

50-59

60-69

$70-79$

․ $80+$

14. Please rate your familiarity with the following LGBT-related terms:

\begin{tabular}{|l|l|l|l|l|l|}
\hline & $\begin{array}{l}\text { Never } \\
\text { Heard }\end{array}$ & $\begin{array}{l}\text { Heard, but not } \\
\text { Familiar }\end{array}$ & $\begin{array}{l}\text { Somewhat } \\
\text { Familiar }\end{array}$ & Familiar & $\begin{array}{l}\text { Very } \\
\text { Familiar }\end{array}$ \\
\hline Bisexual & & & & & \\
\hline Cisgender & & & & & \\
\hline Female-to-Male (FTM) Transgender & & & & & \\
\hline Gay & & & & & \\
\hline Gender Binary & & & & & \\
\hline Gender Identity & & & & & \\
\hline Gender Variant & & & & & \\
\hline Genderqueer & & & & & \\
\hline Homosexuality & & & & & \\
\hline Lesbian & & & & & \\
\hline Male-to-Female (MTF) Transgender & & & & & \\
\hline Sexual Orientation & & & & & \\
\hline Transgender & & & & & \\
\hline Queer & & & & & \\
\hline Questioning & & & & & \\
\hline
\end{tabular}

15. Please rate how comfortable you would be in these same scenarios:

\begin{tabular}{|l|l|l|l|l|l|}
\hline & $\begin{array}{l}\text { Very } \\
\text { Uncomfortable }\end{array}$ & Uncomfortable & Neutral & Comfortable & $\begin{array}{l}\text { Very } \\
\text { Comfortable }\end{array}$ \\
\hline $\begin{array}{l}\text { Aiding a college student in } \\
\text { locating primary sources } \\
\text { (newspaper articles, interviews, } \\
\text { and the like) for a class } \\
\text { assignment on the LGBT } \\
\text { Stonewall riots. }\end{array}$ & & & & & \\
\hline
\end{tabular}




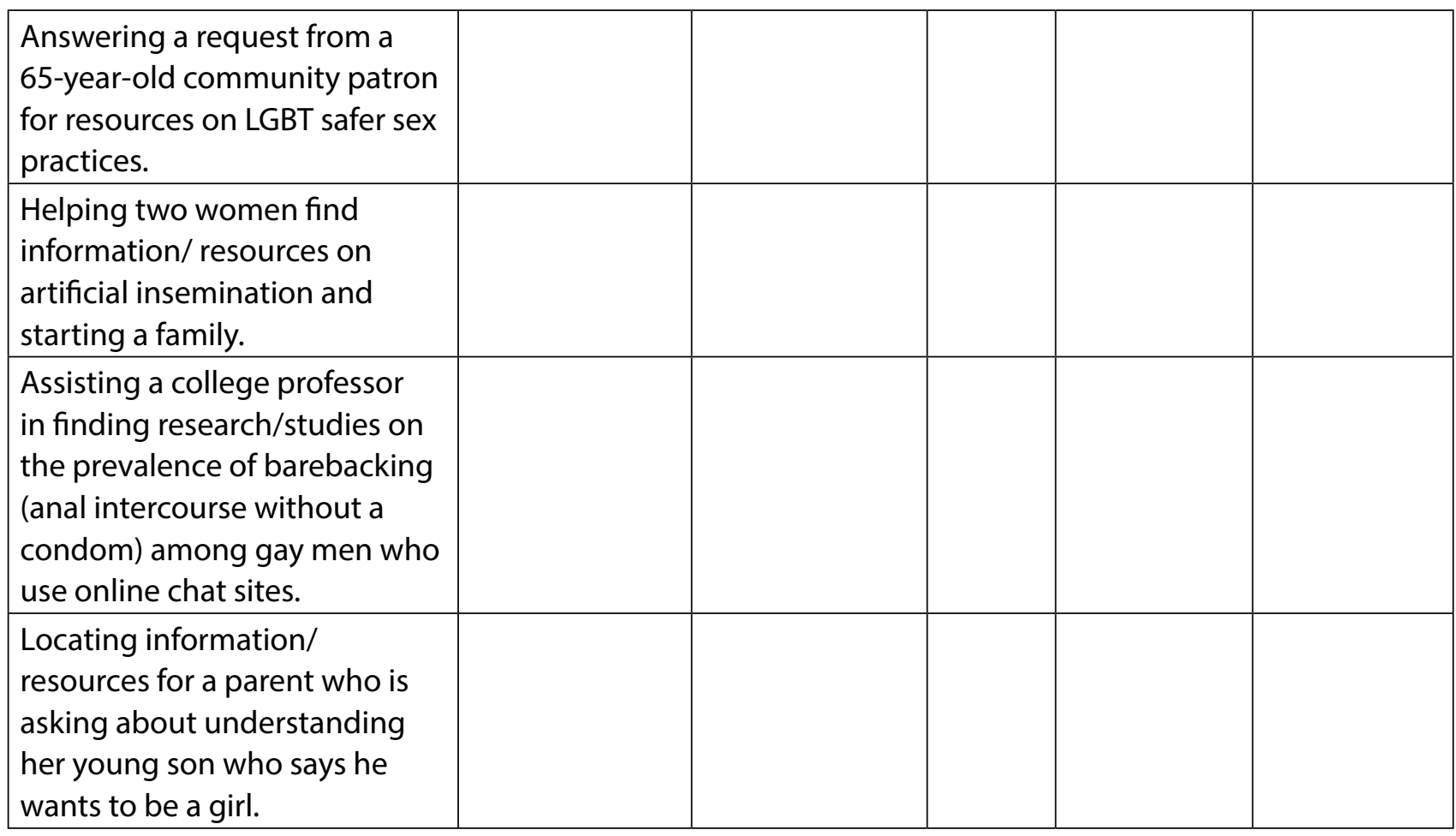

16. Please rate how comfortable you would be in these sample scenarios:

\begin{tabular}{|c|c|c|c|c|c|}
\hline & \begin{tabular}{|l|} 
Very \\
Uncomfortable
\end{tabular} & Uncomfortable & Neutral & Comfortable & $\begin{array}{l}\text { Very } \\
\text { Comfortable }\end{array}$ \\
\hline $\begin{array}{l}\text { Providing recommendations } \\
\text { for books, websites, and } \\
\text { other sources to a high } \\
\text { school teacher planning an } \\
\text { antibullying campaign that is } \\
\text { LGBT inclusive. }\end{array}$ & & & & & \\
\hline $\begin{array}{l}\text { Helping an adult locate self- } \\
\text { help books or resources that } \\
\text { cover transitioning from male } \\
\text { to female or female to male } \\
\text { (hormone therapy, name } \\
\text { change, employment issues, } \\
\text { and other topics). }\end{array}$ & & & & & \\
\hline $\begin{array}{l}\text { Assisting a teenager (under } \\
\text { 18) who has asked for LGBT- } \\
\text { themed books or films. }\end{array}$ & & & & & \\
\hline $\begin{array}{l}\text { Locating books or resources } \\
\text { for a teenager (under 18) on } \\
\text { "coming out" as gay, lesbian, } \\
\text { bisexual, or transgender. }\end{array}$ & & & & & \\
\hline
\end{tabular}


17. Please rate how comfortable you would be in these sample scenarios:

\begin{tabular}{|l|l|l|l|l|l|}
\hline & $\begin{array}{l}\text { Very } \\
\text { Uncomfortable }\end{array}$ & Uncomfortable & Neutral & Comfortable & $\begin{array}{l}\text { Very } \\
\text { Comfortable }\end{array}$ \\
\hline $\begin{array}{l}\text { Supplementing a library's } \\
\text { collection with bisexual, gay, or } \\
\text { lesbian sexually themed materials } \\
\text { such as The Joy of Gay Sex or The } \\
\text { Whole Lesbian Sex Book. }\end{array}$ & & & & \\
\hline $\begin{array}{l}\text { Based on patron requests, } \\
\text { supplementing a library's } \\
\text { collection with bisexual, gay, or } \\
\text { lesbian sexually themed materials. }\end{array}$ & & & & \\
\hline $\begin{array}{l}\text { Selecting gay, lesbian, bisexual, } \\
\text { and/or transgender materials } \\
\text { (not sexually themed) such as } \\
\text { Legalizing LGBT Families (book) } \\
\text { and Growing Up Trans[gender] } \\
\text { (documentary). }\end{array}$ & & & & & \\
\hline $\begin{array}{l}\text { Based on patron requests, } \\
\text { selecting gay, lesbian, bisexual, } \\
\text { and/or transgender materials } \\
\text { (not sexually themed) for a } \\
\text { library's collection. }\end{array}$ & & & & & \\
\hline
\end{tabular}

18. Please rate your level of agreement with the following statements:

\begin{tabular}{|l|l|l|l|l|l|}
\hline & Strongly Disagree & Disagree & Neutral & Agree & Strongly Agree \\
\hline $\begin{array}{l}\text { I am confident in serving LGBT } \\
\text { information needs. }\end{array}$ & & & & & \\
\hline $\begin{array}{l}\text { I would benefit from training to } \\
\text { help meet LGBT information needs. }\end{array}$ & & & & & \\
\hline
\end{tabular}

19. If offered, which types of training opportunities on serving LGBT information needs might you be interested in? You may select more than one answer.

- None; I am not interested in training opportunities

- Local Conferences/Presentations/Workshops

- Regional Conferences/Presentations/Workshops

- State Conferences/Presentations/Workshops

- Virtual/Online Conferences/Presentations/Workshops/Webinars (live or prerecorded)

- Self-paced online courses (continuing education/not for credit)

- Electronic Discussion Groups [listservs] to ask questions and share information

- If you have additional training interests, please share them below.

20. If you would like to provide additional comments about serving LGBT information needs that may be helpful for this research project, please do so below. Do not include any identifying information, such as personal or institution names. 


\section{APPENDIX B. Characteristics of Respondents Who Are US Academic Librarians:}

Total Responses (US Academic Librarians)

\begin{tabular}{|l|l|l|l|l|}
\hline $\begin{array}{l}\text { Do you identify as lesbian, gay, } \\
\text { bisexual, and/or transgender? }\end{array}$ & \multicolumn{2}{|l|}{$\begin{array}{l}\text { How long have you held the MLS/MLIS } \\
\text { or equivalent? }\end{array}$} \\
\hline No & $243(65 \%)$ & & Less than 1 year & $14(4 \%)$ \\
\hline Yes & $110(29 \%)$ & & $1-4$ years & $105(28 \%)$ \\
\hline Prefer not to disclose & 9 & & $5-9$ years & $94(25 \%)$ \\
\hline No answer & 14 & & $10+$ years & $163(43 \%)$ \\
\hline & & & & \\
\hline Age & & & \\
\hline $18-25$ & $11(3 \%)$ & & & \\
\hline $26-30$ & $50(13 \%)$ & & & \\
\hline $31-39$ & $116(31 \%)$ & & & \\
\hline $40-49$ & $75(20 \%)$ & & & \\
\hline $50-59$ & $71(19 \%)$ & & & \\
\hline $60-69$ & $36(10 \%)$ & & & \\
\hline Prefer not to disclose & 3 & & & \\
\hline No answer & 14 & & \\
\hline
\end{tabular}

\section{Notes}

1. American Library Association, "Library Bill of Rights," available online at www.ala.org/advocacy/intfreedom/librarybill [accessed 12 January 2019].

2. Canadian Federation of Library Associations, "Code of Ethics," available online at http://cfla-fcab.ca/en/ guidelines-and-position-papers/code-of-ethics/ [accessed 23 February 2018]; Medical Library Association, "Code of Ethics for Health Sciences Librarianship," available online at www.mlanet.org/p/cm/ld/fid=160 [accessed 16 January 2018.]; Special Libraries Association, "SLA Professional Ethics Guidelines," available online at https:// www.sla.org/about-sla/competencies/sla-professional-ethics-guidelines/ [accessed 16 January 2018].

3. John Siegel, “Let's Talk About Sex: The Librarians' Response," Journal of Hospital Librarianship 7, no. 2 (June 25, 2007): 1-15, https://doi.org/10.1300/J186v07n02_01; Bharat Mehra and Donna Braquet, "Process of Information Seeking during 'Queer' Youth Coming-out Experiences," in Youth Information-Seeking Behavior II: Contexts, Theories, Models, and Issues, eds. Colleen Cool and Mary K. Chelton (Lanham, MD: Scarecrow Press, 2007), 93-131.

4. Cameron M. Pierson, "Barriers to Access and Information for the LGBTQ Community," Canadian Journal of Information and Library Science 41, no. 4 (Dec. 2017): 245-62.

5. Mahzarin R Banaji and Anthony G. Greenwald, Blindspot: Hidden Biases of Good People (New York, NY: Delacorte Press, 2013).

6. Martha Cornog, "Erotophobia, Homophobia, and Censorship in U.S Libraries: An Historical Overview," Journal of Information Ethics 25, no. 2 (2016): 42-58.

7. Cornog, "Erotophobia, Homophobia, and Censorship in U.S Libraries."

8. Pierson, "Barriers to Access and Information for the LGBTQ Community."

9. Pierson, "Barriers to Access and Information for the LGBTQ Community."

10. Janet A.E. Creelman and Roma M. Harris, "Coming Out: The Information Needs of Lesbians," Collection Building 10, no. 3/4 (Mar. 1, 1990): 37-41, https://doi.org/10.1108/eb023281.

11. Alisa J. Whitt, “The Information Needs of Lesbians," Library \& Information Science Research 15, no. 3 (1993): $275-88$.

12. Steven Joyce and Alvin M. Schrader, "Hidden Perceptions: Edmonton Gay Males and the Edmonton Public Library," Canadian Journal of Information \& Library Sciences 22, no. 1 (Apr. 1997): 19-37.

13. Ann Curry, "If I Ask, Will They Answer? Evaluating Public Library Reference Service to Gay and Lesbian 
Youth," Reference \& User Services Quarterly (2005): 65-75.

14. Curry, "If I Ask, Will They Answer?"; Gregg A. Stevens, "Curry's Study on the Quality of Public Library Reference Service to LGBTQ Youth," Evidence Based Library and Information Practice 13, no. 1 (2018): 57-63, https:// doi.org/10.18438/eblip29399.

15. Pascal Lupien, "GLBT/Sexual Diversity Studies Students and Academic Libraries: A Study of User Perceptions and Satisfaction," Canadian Journal of Information and Library Science 31, no. 2 (2007): 131-47.

16. Lupien, "GLBT/Sexual Diversity Studies Students and Academic Libraries."

17. Rachel S. Wexelbaum, "Do Libraries Save LGBT Students?" Library Management 39, no. 1/2 (Jan. 8, 2018): 31-58, https://doi.org/10.1108/LM-02-2017-0014.

18. Aubri A. Drake and Arlene Bielefield, "Equitable Access: Information Seeking Behavior, Information Needs, and Necessary Library Accommodations for Transgender Patrons," Library \& Information Science Research 39, no. 3 (July 2017): 160-68, https://doi.org/10.1016/j.lisr.2017.06.002.

19. Janice A. Sabin, Rachel G. Riskind, and Brian A. Nosek, "Health Care Providers' Implicit and Explicit Attitudes toward Lesbian Women and Gay Men," American Journal of Public Health 105, no. 9 (2015): 1831-41.

20. Charles R. Fikar and Latrina Keith, "Information Needs of Gay, Lesbian, Bisexual, and Transgendered Health Care Professionals: Results of an Internet Survey," Journal of the Medical Library Association: JMLA 92, no. 1 (Jan. 2004): 56-65; Martin Morris and K.R. Roberto, "Information-Seeking Behaviour and Information Needs of LGBTQ Health Professionals: A Follow-up Study," Health Information and Libraries Journal 33, no. 3 (Apr. 2016): 204-21, https://doi.org/10.1111/hir.12139. 2019]

21. SurveyMonkey, "SurveyMonkey," available online at https://www.surveymonkey.com/ [accessed 4 March

22. Benjamin Zimmer, Jane Solomon, and Charles E. Carson, "Among the New Words," American Speech 89, no. 4 (Dec. 1, 2014): 470-96, https://doi.org/10.1215/00031283-2908233.

23. American Psychological Association, "Key Terms and Concepts in Understanding Gender Diversity and Sexual Orientation among Students" (2015), available online at https://www.apa.org/pi/lgbt/programs/safesupportive/lgbt/key-terms.pdf [accessed 4 March 2019].

24. Lisa Wallander, "Measuring Social Workers' Judgements: Why and How to Use the Factorial Survey Approach in the Study of Professional Judgements," Journal of Social Work 12, no. 4 (July 2012): 364-84, https://doi. org/10.1177/1468017310387463.

25. Fikar and Keith, "Information Needs of Gay, Lesbian, Bisexual, and Transgendered Health Care Professionals."

26. Siegel, "Let's Talk About Sex."

27. Michelle R Adler, Patricia L. Riley, Sheila Bandazi, and Margarett K. Davis, "How Option B+ Is Shifting the PMTCT Paradigm," African Journal of Midwifery \& Women's Health 7, no. 1 (Jan. 2013): 7-13.

28. R Core Team, R: A Language and Environment for Statistical Computing (Vienna, Austria, 2013), available online at www.R-project.org/ [accessed 6 February 2018].

29. RStudio Team, RStudio: Integrated Development for R (Boston, MA: RStudio, Inc., 2018), available online at www.rstudio.com/ [accessed 6 February 2018].

30. William Revelle, Psych: Procedures for Personality and Psychological Research (version 1.8.10) (Evanston, IL: Northwestern University, 2018), available online at https:/CRAN.R-project.org/package=psych [accessed 6 February 2018].

31. Gilles Raiche, NFactors: An R Package for Parallel Analysis and Non Graphical Solutions to the Cattell Scree Test, R Package (version 2.3.3), 2010.

32. Bruno Falissard, Psy: Various Procedures Used in Psychometry (version R package version 1.1) (2012), available online at https://CRAN.R-project.org/package=psy [accessed 6 February 2018].

33. R Core Team, $R$ : A Language and Environment for Statistical Computing.

34. Brett Williams, Andrys Onsman, and Ted Brown, "Exploratory Factor Analysis: A Five-Step Guide for Novices," Australasian Journal of Paramedicine 8, no. 3 (Aug. 2, 2010), https://doi.org/10.33151/ajp.8.3.93.

35. Henry F. Kaiser, "A Second Generation Little Jiffy," Psychometrika 35, no. 4 (Dec. 1, 1970): 401-15, https:// doi.org/10.1007/BF02291817.

36. M.S. Bartlett, “Tests of Significance in Factor Analysis," British Journal of Statistical Psychology 3, no. 2 (1950): 77-85, https://doi.org/10.1111/j.2044-8317.1950.tb00285.x.

37. Zimmer, Solomon, and Carson, "Among the New Words"; American Psychological Association, "Key Terms and Concepts in Understanding Gender Diversity and Sexual Orientation Among Students."

38. Sara A. Howard and Steven A. Knowlton, "Browsing through Bias: The Library of Congress Classification and Subject Headings for African American Studies and LGBTQIA Studies," Library Trends 67, no. 1 (Oct. 25, 2018): 74-88, https://doi.org/10.1353/lib.2018.0026. 
39. Safe Zone Project, “Curriculum,” available online at https://thesafezoneproject.com/curriculum/ [accessed 4 March 2019].

40. Multivariate Data Analysis: With Readings, 4th ed., Joseph F. Hair, ed. (Englewood Cliffs, NJ: Prentice Hall, 1995); Williams, Onsman, and Brown, "Exploratory Factor Analysis."

41. Frank Newport, "In U.S., Estimate of LGBT Population Rises to 4.5\%," Gallup.com (May 22, 2018), available online at https://news.gallup.com/poll/234863/estimate-lgbt-population-rises.aspx, [accessed 11 December 2018].

42. Renee F. Hill and Meagan M. McGrath, "Chapter 5: Why Is the Conversation about LGBT Students? Information Needs Still in the Closet? The Role of the MLIS Program in Preparing Culturally Competent School Librarians," in Re-Envisioning the MLS: Perspectives on the Future of Library and Information Science Education, 44B:71-82, Advances in Librarianship 44B (Bingley, UK: Emerald Publishing Limited, 2018), https://doi.org/10.1108/ S0065-28302018000044B006. 